\title{
Implementation of Premarital Counseling To Improve Youth Understanding Against Marriage Maturity Age
}

\author{
$1^{\text {st }}$ Diana Ariswanti Triningty as \\ Fakultas Keguruan dan Ilmu Pendidikan \\ Universitas PGRI Madiun \\ dianaariswanti@unipma.ac.id
}

\author{
$2^{\text {nd }}$ Siti Muhayati \\ Fakultas Keguruan dan Ilmu Pendidikan \\ Universitas PGRI Madiun \\ sitimuhay ati10@gmail.com
}

\begin{abstract}
Information about sex, is not a taboo in a modern life like today. It is very important given to adolescents, considering entering adolescence sexual maturity has begun to develop. Hormonal function increases and causes arousal. It can not be denied that, almost in all the big cities and also in the village, the number of cases of teenagers who have sex outside of marriage. Various factors that underlie teenagers do this, among others is due to lack of attention from parents, deep curiosity, the desire to try, the influence of video / porn stories, lack of knowledge possessed of information about free sex. The tendency to have free sex in adolescence can lead to marriage at an early age. Adolescents need to be equipped with knowledge and understanding of the age of a good marriage, in accordance with the physical and mental development. The ideal age of marriage for women is over 20 years, while for men over 25 years. Marriage at an early age may increase the risk of maternal mortality, one of the reasons is that too young age during pregnancy. Based on the phenomenon, the implementation of prenuptial counseling through information and consultation services is expected to increase adolescent understanding of maturation age marriage (PUP).
\end{abstract}

Marriage

Keywords- Premarital Counseling, Maturing Age of

\section{INTRODUCTION}

A phenomenon that is quite apprehensive when viewing impressions on television and news in newspapers that preach about criminality, violence, substance abuse, sexual abuse and free sex conducted by teenagers. Information about sex, is not a taboo in a modern life like today. It is very important given to adolescents, considering entering the age of adolescence sexual maturity has begun to develop. Hormonal function increases and causes arousal. It can not be denied that, almost in all the big cities and also in the village, the number of cases of teenagers who have sex outside of marriage. According to the Indonesian Child Protection Commission (KPAI) survey, that in big cities in Indonesia in 2012 as many as $32 \%$ of teenagers aged 14-18 have had sex. Various factors that underlie teenagers do this, among others is due to lack of attention from parents, curiosity, the desire to try, the influence of video / porn stories, lack of knowledge possessed of information about free sex. The tendency to have free sex in adolescence can lead to marriage at an early age.

Even early marriage is prohibited by law, it still happens in many communities. A study conducted by the United Nations
Children's Fund (UNICEF), early marriage phenomena is still common in communities in the Middle East and South Asia and in some communities in Sub Saharan Africa [1]. In a study conducted by Triningtyas \& Muhayati [2], revealed that in the community in Pulung Ponorogo, married young age is commonplace and ordinary. According to Triningtyas \& Muhayati [2], that happiness in a marriage is a dream for every couple. Therefore, marriage must be viewed and addressed as something serious and important. Preparedness in a marriage is necessary both in terms of social life, economic, physiological and psychological. Not a few couples are less aware of the need for a mature readiness. This is proven by the increasing number of teenagers who married at an early age / young.

Adolescents need to be equipped with knowledge and understanding of the age of a good marriage, in accordance with the physical and mental development. The ideal age of marriage for women is over 20 years, while for men over 25 years. Marriage at an early age may increase the risk of maternal mortality, one of the causes is too young age during pregnancy. Based on the phenomenon, the implementation of prenuptial counseling through information and consultation services is expected to improve adolescent's understanding of maturation age (PUP).

\section{DISCUSSION}

According to Triningtyas \& Teta [3], this modern life creates a complex life dilemma, the emergence of an increasingly complex and difficult to overcome life problem. These rapid changes are not uncommon for a positive impact and some are negative, which is unpleasant in the form of pressure for the individual. The negative impacts that occur such as crime, violence, drug abuse, sexual harassment, and premarital sex.

According to Melodina [4], that premarital sex is a sexual relationship performed by a pair of unmarried people or those who have not been bound by the marriage cord. Sex behavior that is considered to violate the norm is not a new thing.

Impacts of misbehavior such as premarital sexual intercourse are carried out unsafe so as to cause unexpected pregnancy (KTD) on the part of women or the transmission of sexually transmitted infections. This is in line with the opinion of Sarwono [5], that sexual behavior in adolescents influenced by several factors, such as hormonal changes, promiscuity, 
lack of adolescent understanding of sexual maturity, and lack of information about sex. The assistance services that can be provided to adolescents to sex life is through the implementation of prenuptial counseling through information and consulting services.

\section{A. Premarital Counseling}

The term pre-marital counseling is also known as prenuptial education, prenuptial educational counseling, prenuptial therapy, and marriage preparation programs. According to Triningtyas [6], prenuptial counseling is a counseling process given to prospective partners to know, understand and accept for them to be ready for birth and mind before deciding to take a marriage. In the process of recognizing, understanding and accepting this does not involve only two partners. But this relationship will involve the two big couples. It is not easy to accept the characteristics of each different person, if we do not know and understand them well [7].

The purpose of prenuptial counseling, not only to solve problems that occur only. However, how to prepare couples to live together in the future. Through this goal, it is expected to be able to build and build a harmonious family.

Pre-marital counseling targets, not only intended for potential couples who have is sues related to marriage only, but this must be followed by all prospective couples who will carry out the marriage. This is more of a guide and guidance in married life, although it does not rule out the possibility of clearing up, resolving and resolving existing issues, either personally or in the relationship between the couple or with family and others.

In the implementation of prenuptial counseling, it can generally be done through information and consulting services. The purpose of this information service is the provision of information service assistance for adolescents in order to make decisions appropriately and correctly based on the information obtained. Through information services, adolescents can receive and understand various information, but it can also serve as a prevention or understanding. Consultation services, is a provision of assistance in gaining insight, understanding, and ways that need to be implemented in addressing the conditions and or problems faced by adolescents. Consulting services are not a service that is intended for clients, but indirectly this consulting service serves clients through the assistance provided by others. Implementation of prenuptial counseling provides assistance in the form of information and consultation on the problems faced by adolescents, early marriage and problem, the age of marriage is mature, open communication, marriage/ pregnancy, the healthy behavior of young people, reproductive health, settlement. conflict, or discuss sensitive topics such as sex, finances, relationships with in-laws, domestic violence.

\section{B. Maturing Age of Marriage (PUP)}

Maturing marriage age (PUP), is an attempt to increase the age at first marriage to reach the minimum age at the time of marriage that is 20 years (for women) and 25 years (for men). Maturing Marriage Age, not just postpone until a certain age only but make sure that the first pregnancy occurs at a fairly old age.

The purpose of this PUP is to provide understanding and awareness to adolescents so that in planning their families, they can consider various aspects related to family life, physical, mental, emotional, educational, social, economic and determine the number and distance of birth.

The factors that encourage marriage at a young age are economic factors, educational factors, parents factor, self, and local custom. From economic factors, early marriage occurs due to family economic conditions are still lacking or mediocre just so that to lighten the burden of his parents, then her daughter married with a potential partner who is considered capable. Educational factors, due to the low level of education of parents and children so that this affects their mindset in understanding the meaning and purpose of marriage. This causes the tendency of marriage at an early age. Parents factor, occurs because of a sense of concern experienced by the parents. factor of self, has a very big role also influence and dominate the occurrence of early marriage. This happens because of the influence of the environment / friends. Local customary factor, this "old spinster" image haunts the elderly and encourages her to get married at a young age sooner than later (married).

\section{CONCLUSION}

It is expected for parents, to communicate intensely and be open to the child. Through a good and true understanding of sex education, will be able to make teenagers to do other positive things in life.

\section{References}

[1] Landung, J., et al (2009). Studi Kasus Kebiasaan Pernikahan Usia Dini Pada Masyarakat Tana Toraja. Jurnal MKMI. Vol 5, No. 4, Oktober 2009, hal 89-94.

[2] Triningtyas, D.A. \& Muhayati, S. (2017). Konseling Pranikah : Sebuah Upaya Mereduksi Budaya Pernikahan Dini di Kecamatan Pulung Kabupaten Ponorogo. Jurnal Konseling Indonesia, Vol. 3, No. 1, Tahun 2017.

[3] Triningtyas, D.A. \& Maela, T. (2014). Optimalisasi Peran Konselor Dalam Pengembangan Karakter Peserta Didik. Prosiding Seminar Nasional Bimbingan dan Konseling "Pemberdayaan Bimbingan dan Konseling Sekolah". ISBN. 978-979-028-717-4. Surabaya : Psikologi Pendidikan dan Bimbingan Program Studi Bimbingan dan Konseling Universitas Negeri Surabaya.

[4] Melodina, P. (1990). Kesehatan Mental Remaja Putri Yang Telah Melakukan Hubungan Seksual Pranikah. Skripsi. Depok : Fakultas Psikologi Universitas Indonesia.

[5] Sarwono. (2004). Psikologi Remaja. Jakarta : PT. Raja Grafindo Persada.

[6] Triningtyas, D.A. (2017). Sex Education. Magetan : AE Media Grafika. 
[7] A. B. N. R. Putra, W. Irdianto, A. Mukhadis, and S. Suhartadi, "Pocket Book Learning: Learning Methods to Train Students Productive and Creative Using 'BRANO' as an Effective Learning Recorder," in Proceedings of the International Mechanical Engineering and Engineering Education Conferences (IMEEEC-2016), 2016, vol. 30034, p. 30034. 